\title{
E-Service Quality and Customer Loyalty in Deposit Money Banks in Nigeria
}

\author{
${ }^{1}$ Osagie Leslie Uwabor Ph.D* $\quad{ }^{2}$ Professor Geraldine Ugwuonah \\ Department of marketing, University of Nigeria, Enugu Campus - Nigeria \\ Corresponding Author: Osagie Leslie Uwabor' P.M.B 488 Uniport Post Office, Port Harcourt Nigeria
}

\begin{abstract}
The study examined Electronic Service Quality and Customer Loyalty in Deposit Money Banks in Nigeria. Its aim was to assess the level of relationship between e-service quality and customer loyalty of deposit money banks in Nigeria. In line with the objective of the study, three null hypotheses were formulated to guide the research. The theoretical foundation of the study was based on resource base and sustainable theories. The study adopted quasiexperimental research design. The population size was drawn from the customer of quoted deposit money banks with international authorization in Nigeria. A sample size of 411 customers was obtained using Krejcie and Morgan formula. A probability simple random sampling technique was further utilized in picking the respondents. A questionnaire of five point likert scale was used in data collection. Frequency, percentages, bar and pie charts were used in analyzing both the demographic data of the respondents, mean and standard deviation to answer research questions, while Kendall tau_b correlation coefficient was employed in testing the hypotheses formulated for the study. All the null hypotheses were rejected. The research therefore revealed that; a significant relationship exist between interactivity and customer loyalty of deposit money banks in Nigeria, a significant relationship exist between customer support and customer loyalty of deposit money banks in Nigeria, as well that there is a significant influence of customer technology adoption on the relationship between e-service quality and customer loyalty. It was concluded that, quality of e-service have help to improved customer loyalty in deposit money banks. It was therefore recommended amongst others that, deposit money banks should develop their websites by making it more interactive, online banking should be made easier for customers to make use of, and that more awareness should be given to customers on the need for e-banking.
\end{abstract}

Keywords: Electronic, Service, Quality, Customer, Loyalty, Deposit, Money, Bank

DOI: $10.7176 / \mathrm{EJBM} / 12-21-04$

Publication date:July $31^{\text {st }} 2020$

\section{Introduction}

It is believed that the goal of every organisation is to meet the needs and requirements of its stakeholders. Meeting the needs and the requirements of the stakeholders will not only ensure the survival of the organisation but also allow it to flourish. Customers are presumed to be one of the most critical stakeholders in any organization because, without them, organizations are not likely to succeed. Knowledge of consumer behaviour will go a long way in ensuring effective marketing policies towards the interest of customers which will eventually facilitate positive customer attitude towards the organisations. More especially, since customer behavioural intention is a strong indication of his actual behaviour.

As a result of financial sector liberalisation in Nigeria in the 1980s, the banking sector experienced a boom. Low entry requirements by the regulatory authority and the high premiums earned through foreign exchange business led to the quick entry by new players into the lucrative banking industry. Between the period of 1985 and 1993, the number of licensed banks rose astronomically from 41 to 120 (Central Bank of Nigeria, 1995), leading to the increase in the sector's contribution to GDP and employment.Therefore, it can be argued that banks in Nigeria contribute a significant percentage of the country's GDP in the recent past considering that banks are important constituents of the industry (Adeoye, 2007).

The operational impact of the Nigerian banking sector is felt across many African countries such that a problem in the Nigerian banking sector could have an adverse spillover effect on other African countries (Anaro, 2009).

With the rapid growth of the Internet and the globalisation of market, companies accepted and adopted the new information and communication technology in the performance of their activities, not only to support traditional activities, but also to support those arising from new opportunities, mainly from the Internet. Electronic commerce and online business stand out among these opportunities. Most companies are establishing Websites, which are regarded as a new channel to conduct a business transaction, and customers can purchase companies' products/ services through their websites. It enables companies to access a global market with low operating cost, to offer information in depth, and to provide customers electronic service (e-service) with superior quality using the interactivity of the Internet, which increases the competition among companies (Sohn \&Tadisina, 2008).

Effective e-service quality in banking is one of the most important ways to keep customers coming back despite the hurdles in the Nigeria banking sector. The strategies to maintain customers confidence includes 
responding to customers' complaints in a thorough and timely manner and interacting with customers through face to face meeting, telephone, mail, fax and email. This significant contribution of the services industry and specifically the banking sector in Nigeria warrant investigation in order to enhance the sector's continuous growth which will eventually result in the better performance of the economy. However, it is important to note that one of the ways through which banks can meet the expectations of their customers who are the anchor of the banks' business is via the understanding of the customers' behaviour.

Owing to the relevance of e-service quality for retaining customer loyalty, many scholars have empirically investigated this area of study. For instance, Sohn and Tadisina (2008) studied "Development of e-service quality measure for the Internet-based financial institutions. Lin and Lee (2005) examined "Customer perceptions of eservice quality in online shopping. Yang (2001), examined Consumer perceptions of service quality in Internetbased electronic commerce. There are very few scholarly inquiries that simultaneously measure e-service quality against customer loyalty of deposit money banks. Therefore, this study attempts to bridge such knowledge gaps. Thus, this study offers a more holistic framework of two dimensions of e-service quality and isolated the effect of each on the measure of customer loyalty. Our point of departure is, therefore, to empirically investigate the influence of e-service quality on customer loyalty in deposit money banks using Nigeria as our case study.

\section{Statement of the Problem}

The dynamic nature of the financial system and its business environment is creating the need to focus more on the customer rather than the product in order to be competitive. The banking industry has been characterised by the emergence of different channels of banking such as Internet banking, Automated Teller Machines (ATM), phone banking and global competition that are forcing bankers to explore the importance of customer loyalty and maintaining lasting relationships with customers. Banks management needs to develop strategies that will differentiate them from their competitors. Competitive advantage can be created through the delivery of higheservice quality. E-service quality has been proven to lead to customer loyalty (Caruana, 2002). Excellence in eservice quality is a key to achieve customer loyalty which is the primary goal of business organisations, due to the advantages of customer retention (Ehigie, 2006).

Customers demand efficient, fast and convenient services. Customers want a Bank that will offer them services that will meet their particular needs (personalised Banking) and support their Business Goals. E-banking came into existence in order to fill the vacuum created by adoption of traditional techniques afore adopted in the Nigeria banking system such as delay of service, lack of information backup, lack of interconnectivity and networks failure. Furthermore, the conclusion of (Salem \& Rashid, 2011) that customer satisfaction has not been explicitly studied for banking sector firms for technology adoption called for an informed empirical investigation.

Deloitte employee survey (2005), found that only nineteen percent (19\%) of bank customers are characterised as truly loyal to their bank, with their conclusion that this proportion was the same in the USA and Europe.

Yousaf and Steen (2011), found that e-service quality presence and intensity can predict higher productivity and profits on hotel performance and customer satisfaction. In the light of the above, it is likely that the benefits of the application of electronic service quality in the marketing of bank services could also improve the level of customer loyalty in deposit money bank. Incidentally, empirical literature in the area of e-service quality and customer loyalty of deposit money banks in Nigeria is very scanty due to limited research in this aspect. As a result, there is a need to fill the knowledge gap in existing literature. Chen and Yen (2004) carried out a study on Improving the Quality of Online Presence through Interactivity; the researchers thus built on this framework by introducing problem tolerance as a measure for loyalty in filling the gap in literature.

Given the uncertainty of electronic service quality and a problem of loyalty in the banking industry, this study seeks to ascertain the extent to which e-service quality can aid customer loyalty in sustaining banks competitive advantage. It is against this backdrop that the researchers intend to investigate e-service quality and customer loyalty of deposit money in Nigeria.

\section{Objectives of the Study}

This study focuses on determining the relationship between e-service quality and customer loyalty of deposit money banks in Nigeria. Hence, the objectives of the study are as follows:

1. To ascertain the extent of relationship between interactivity and customer loyalty of deposit money banks in south- south Nigeria

2. To evaluate the relationship between customer support and customer loyalty in deposit money banks in south-south Nigeria

3. To determine the impact which customer technology adoption has on e-service quality and customer loyalty in deposit money banks in Nigeria.

\section{Research Questions}

In this section of the study, the following research questions were derived; 
1. To what extent does interactivity influence customer loyalty in deposit money banks in Nigeria?

2. To what extent does customer support influence customer loyalty in deposit money banks Nigeria?

3. To what extent does customer technology adoption influence e-service quality and customer loyalty in deposit money banks in south-south Nigeria?

\section{Research Hypotheses}

Derived for the study are the following null hypotheses;

Ho1: There is no significant relationship between interactivity and problem tolerance in deposit money banks in Nigeria

Ho2: There is no significant relationship between customer support and problem tolerance in deposit money banks in Nigeria

Ho3: There is no significant influence of customer technology adoption on the relationship between e-service quality and customer loyalty in deposit money banks in Nigeria.

\section{Review of Related Literature}

The premise of e-service quality as the competitive edge in gaining market leadership has gained significant attention from both practitioners and scholars. The banking industry, in particular, recognised the need not only to attract customer but also to maintain a long-term relationship with customers in order to create a competitive edge in an ever-growing business environment.

This aspect of the study covers the review and discussion of published researched materials relating to e-service quality and customer loyalty. The review of literature in this study will include an emphasis on the theoretical foundation and conceptual framework carried out on e-service quality and customer loyalty in the field of customer relationship marketing.

\section{Theoretical Foundation}

This study is based on the resource-based and sustainable theory which is used to determine the strategic resources with the potential to deliver comparative advantage to a firm. The theory explores the relationships between resources, capabilities, competition and profitability (Osagie, Justie \& Ezechirinum, 2019).

The study, therefore, reviewed the following theories and models as a background to evaluating the extent to which e-service quality under study is guided by some of these leading theories and models of customer relationship marketing.

1. E-service Quality Theory (Santos, 2003)

2. IT Alignment Model (Berkley \& Gupta, 1994)

\section{E-Service Quality Theory: Model of Virtual Service Quality Dimensions (Santos, 2003)}

According to Santos (2003), research into service quality has been popular for more than two decades. However, its application to the e-commerce environment is very recent. Developed from internet marketing and the traditional service quality literature, the concept of service quality in e-commerce (e-service quality) can be defined as the consumers overall evaluation and judgment of the excellence as well as quality of e-service offerings in the virtual market place.

Santos (2003) proposes a conceptual model of e-service quality with its determinants. It can be said that eservice quality has to do with proper design of a website, how technology is used to provide consumers with easy access, understanding and attractions of a website and active dimensions such as good support, fast speed, and attentive maintenance that a website can provide to its customers for increasing hit rates, stickiness, and customer retention. Tracing the development of the models in the literature is fascinating. The growth of literature in the field of service quality seems to have developed sequentially, providing a continuous update and learning from the findings of predecessors. 


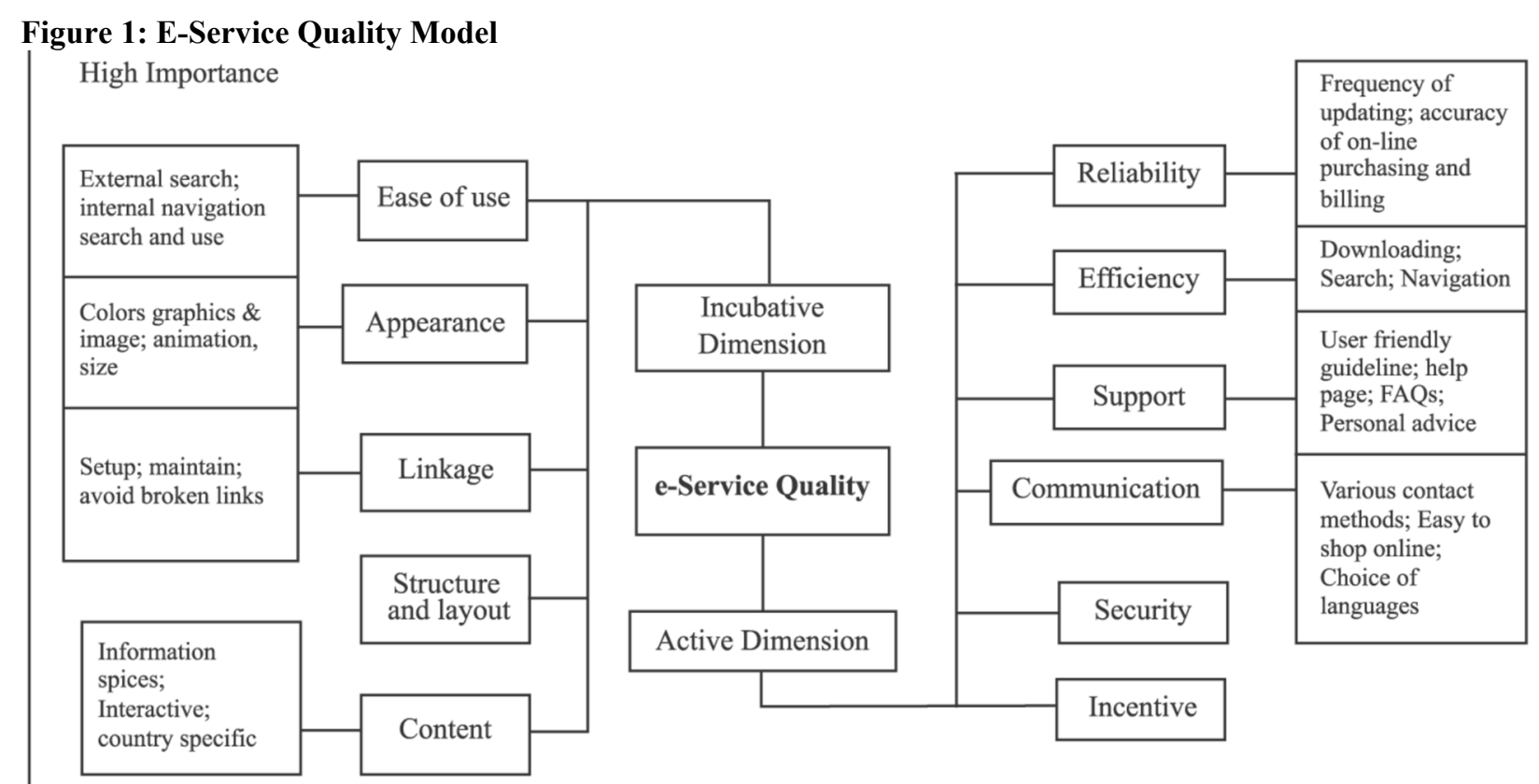

\section{Low Importance}

\section{Source: Santos (2003)}

Furey (1991) suggests that IT can help enhance service quality by increasing convenience, providing extra services, and collecting service performance information for management use. The increased importance of IT motivated researchers to understand better how service customers evaluate IT-based services and how their evaluations affect their perceptions of the overall service quality of the service provider and their satisfaction leading to the related developments of models by Santos (2003).

From the review, it is clear that there does not seem to be a well-accepted conceptual definition of a model of service quality nor there is any generally accepted operational definition of how to measure service quality. However, the majority of models and definitions support the view of evaluating service quality by comparing their service quality expectation with their perceptions of service quality they have experienced.

\section{IT Alignment Model (Berkley \& Gupta, 1994)}

Investments in information technology (IT) sectors usually aim at the productivity of efficiency gains with a little attention to improving customer service and long-run customer effectiveness. This model links the service and the information strategies of the organisation. It describes the use of IT for improving service quality through some case studies from a variety of sectors (banking, courier, transportation and manufacturing industries). 
Figure 2: IT Alignment Model of Service Quality Models

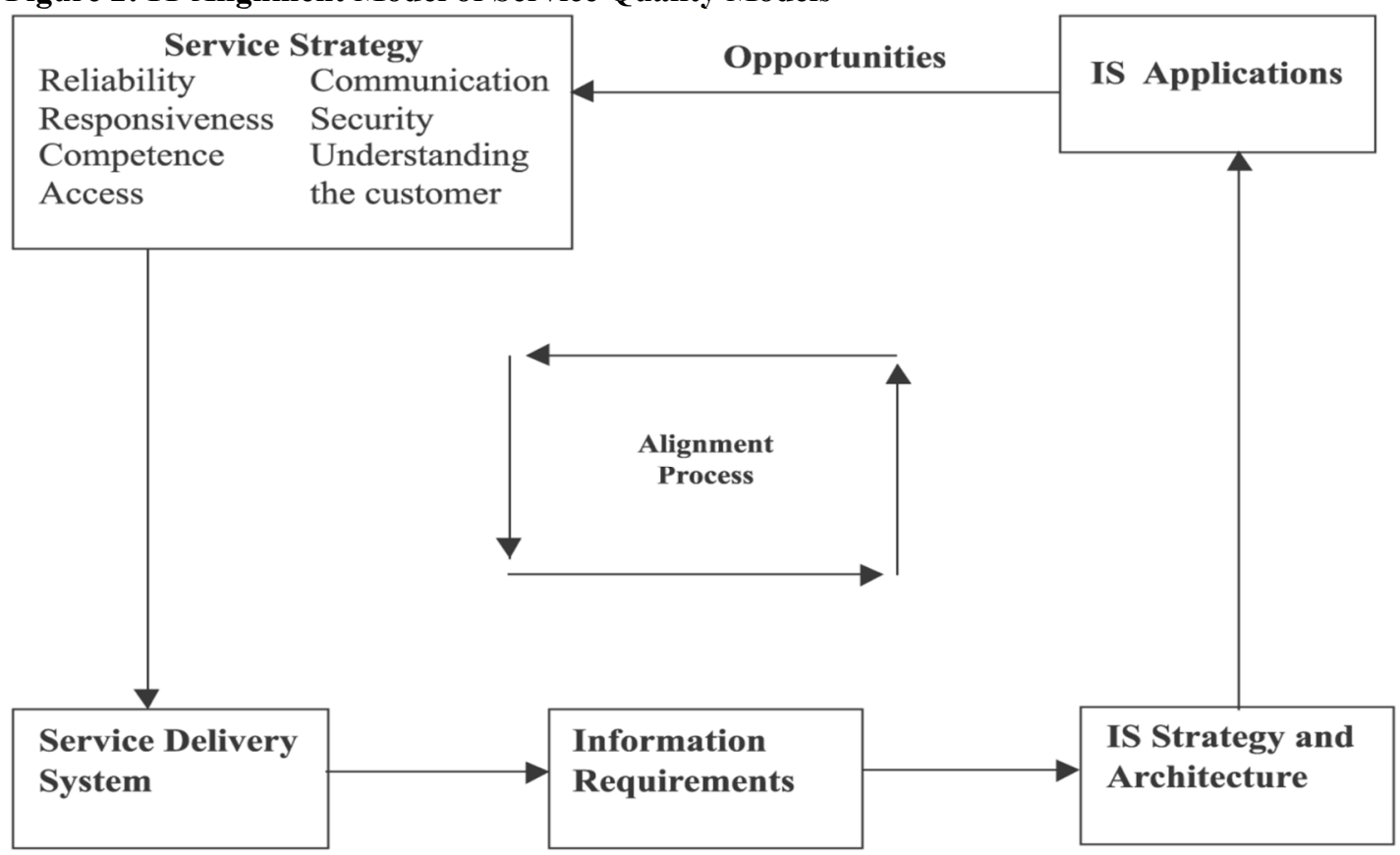

Source: Berkley and Gupta (1994)

This model describes in detail where IT had been used or could be used to improve specific service quality dimensions including reliability, responsiveness, competence, access, communications, security, understanding and knowing the customers. Through some case studies, use of IT for quality control (collect customer data, monitor operations and facilitate service) is also demonstrated.

According to the model, it is crucial that service quality and information system strategies must be tightly coordinated and aligned. The model explains the process of aligning service and aligning strategies.

Figure 3: Conceptual Framework

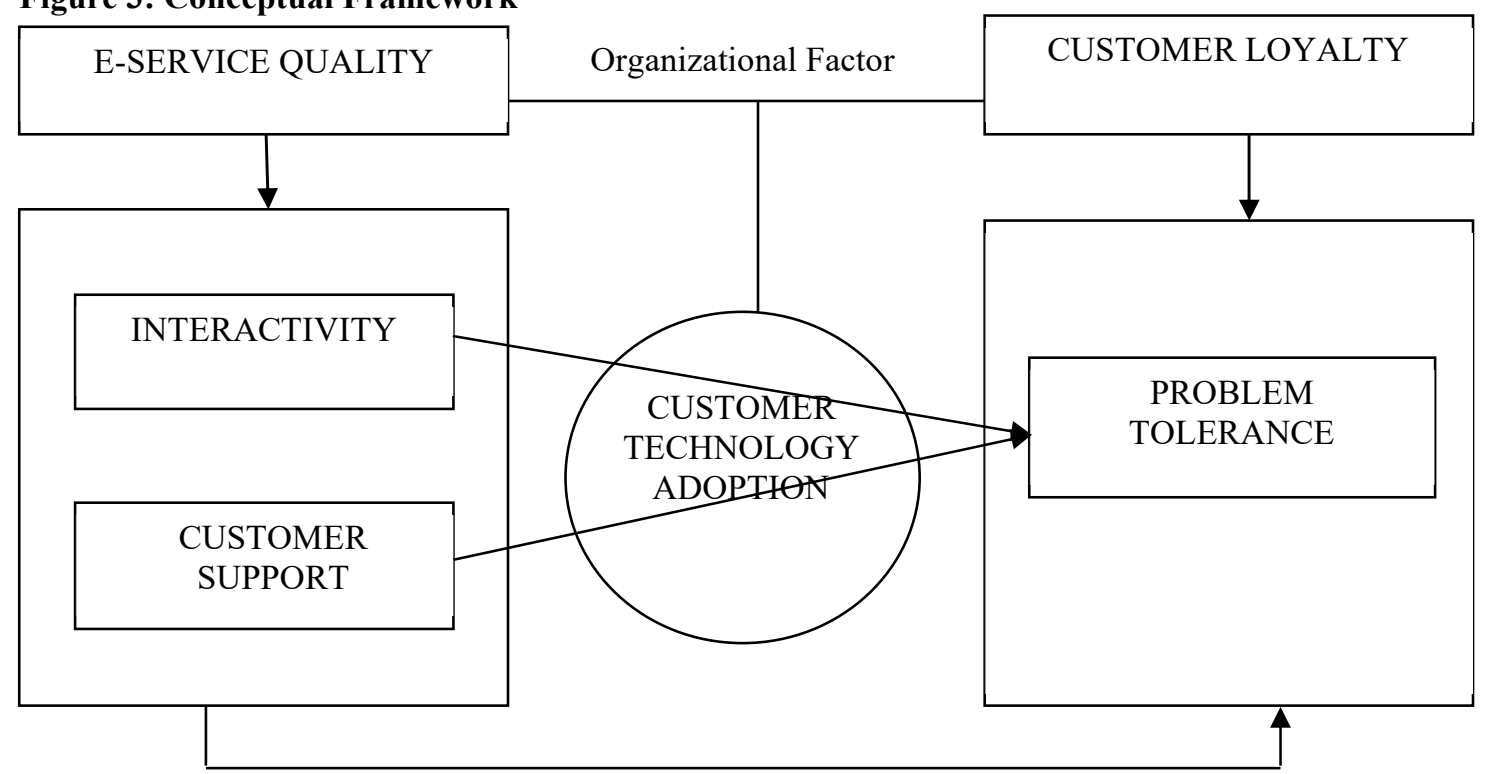

Conceptual Framework of the Relationship between e-service quality and customer loyalty in deposit money banks in Nigeria

Source: Chen and Yen (2004) and Researchers Concept, 2020.

Having extensively reviewed literature on e-service quality and customer loyalty of deposit money bank, the researcher came up with figure 3 as a model of the relationship between electronic service quality with dimensions as interactivity and customer support while customer loyalty was measured with problem tolerance with the moderating variable as customer technology adoption. 


\section{E-Service Quality}

Electronic service or e-service as it has become more commonly known is considered one of the critical determinants for successful e-business Jamie and Aron (2010). With an increase of e-service adoption in the business field, the importance of virtually measuring and monitoring e-service quality becomes recognisable. Over the past two decades, there has been a significant advancement in service quality theory Brady, Robertson and Cronin (2001).

Zeithaml, Parasuraman and Malhotra (2002) defined e-service quality as the extent to which a website facilitates efficient and effective shopping, purchasing and delivery of products and services. The conceptualisation of service quality has its roots in the expectancy disconfirmation theory. Thus, the evaluation of service quality results from comparing the perception of service received to the prior expectation of what the service should provide (Choi, Cho, Lee \& Kim, 2004).

According to Lee and Lin(2005) online customers in general always expect an equal or higher level of service quality than traditional channel customers with a number of factors predicting customer's perception of e-service quality such as; the degree of user-friendliness, reliability and security, responsiveness helpfulness and trust mechanisms provided by a website. Fassnacht and Koese (2006) recommend that service providers should provide quality service because it is a source of competitive advantage. The success or failure of an online business, therefore, depends on the extent to which service providers provide quality service.

More recently, Belanche, Casaló and Flavián (2011) suggest that the use of online services is determined by the perceived usefulness, the attitude toward its use and the perceived control. Consumers will weigh up these advantages and disadvantages when deciding whether or not to use an SST. The Internet has become one primary type of self-service base technology (SST).

\section{Dimensions of E-Service Quality}

For this research study, consideration was given to two dimensions of e-service quality thus: interactivity and customer support.

\section{Interactivity}

The word "interactive" is often employed as a synonym for new media such as the World Wide Web. Advertising practitioners and researchers use the phrase "interactive advertising" to describe Internet or Web-based advertising. However, despite widespread uses of such terms, scholars have noted that interactivity is often either undefined or under-defined.

Thorson and Rodgers (2006) define Website interactivity as "the extent to which users perceive their experiences as a simulation of interpersonal interaction and since they are in the presence of a social other."Cyr, Hassanein, Head and Ivanon (2009) also define Website interactivity as permitting users to control and to retrieve information of the Website in distinct manners. A comparable definition is proposed by $\mathrm{Wu}$ (2011), who defined Website interactivity "as a psychological state undergone by a site-visitor during the interaction process".

Gao, Rau and Salvendy (2009) define interactivity in the context of mobile advertisement as a communication process that presents mobile users' active control, two-way communication, synchronicity, and playfulness. To examine how Website interactivity (user control and two-way communication) exerts a strong influence on Website involvement which in turns impact purchase intentions. Jiang, Chan, Tan and Chua (2010) define Website interactivity as the degree at which individuals may contribute in adjusting the content of a Website while visiting the site.

Voorveld and Van (2013) define Website interactivity as the extent to which two interconnecting groups may impact on each other, the medium, the message, and the degree of impact coordination. Wang, Meng and Wang (2013) agree with Wu's definition stating Website interactivity as a state experienced by the user through the interactive procedure.

Auger (2005) suggests that interactivity is one of the essential design components in any commercial Website. The significance of interactivity for Internet-based e-commerce arises principally from its capacity to have a positive short and long-term impact on customer perception and behaviour.

The interactivity of an e-commerce site provides simplified communications, personalisation of given information, image control, and entertainment for the consumer (Mathwick, 2002). This allows consumers to manage their individual encounters and communication (Lowry, Spaulding, Wells \& Moody ...... 2006).

\section{Customer Support}

Customers are the heart of every successful business and therefore businesses need to be more concentrated on customers than more ever. Except those who donate blood voluntarily, one is either selling a service or a product for a living. Politicians, bankers, clerks, messengers, bus conductors, ticket agents, market women and everyone who provides a trade or service has a customer. According to Scott (2002), Customer support service is a series of activities designed to enhance the level of customer satisfaction, that is, the feeling that a product or service has 
met the customer expectation. The level of satisfaction can also vary depending on other options the customer may have and other products against which the customer can compare the organisation's products.

In today's business world customer support has become one of significant function for every company either it is manufacturing or service based. The recent competitive market has compelled feel necessity to every company either service provider or manufacturing based company, almost all of them are offering customer support in their marketing practices (Vargo \&Lusch, 2004).

Loomba (1998) defined Customer support as a set of activities that ensures product availability for troublefree use to consumers over its useful lifespan. Goffin and New (2001) explained that customer support service is seen as product support, added value, and after-sales service. For every service provider, customer support is compulsory in order to achieve customers' satisfaction.

Companies are increasingly looking to customer support as a source of competitive advantage to win market share. In this technological revolutionary era, it is hard to use every appliances without the support of technical persons and to reduce this gap of knowledge regarding products, almost every company are emphasising more on customer support, thus playing a vital role in high technology based company (Goffin, 1994; Lawless \&Fisher, 1990). Excellent customer support is essential for succeeding customer satisfaction. It can increase the success rate of services and can directly contribute to competitive advantage.

In customer relationship research, customer support has often been viewed as isolated from the core service and studied focusing on, e.g. critical proceedings subsequent in complaining and switching (Roos \& Edvardsson, 2008).

Some of the main challenges in customer service in banking includes a poor data base, management of customers, illiteracy level of the majority of customers, lack of adequate infrastructure and technology on which customer satisfaction depends on like electricity (for ATM operations) and low level of internet penetration. The importance of technology in banking became obvious when developed countries that had involved IT in its banking operations managed to reduce their costs of operations (Daily Graphic, 2008).

\section{Customer Loyalty}

Initially, brand loyalty was investigated for tangible goods. Thus, Brand loyalty was defined as the number of purchases a household allocated to a brand over a specified period. The conceptualisation and measurement of the loyalty concept have become more and more complex (Jones \& Taylor, 2007).

Reichheld (2003) maintains that for many of the service organisations he investigated the results showed that loyalty can be measured by utilising only one indicator - willingness to recommend. Thus, his results convey a one-dimensional conceptualisation of loyalty. A further perspective of customer loyalty is that of Chitty, Ward and Chua (2007) who argue that loyalty can be conceptualised by two dimensions, which are behavioural loyalty, indicated by repeat-purchase behaviour and attitudinal loyalty, referring to the innate affective and cognitive facets of loyalty. Zins' (2001) study of the airport sector brought this a step further, identifying three distinctive approaches to measure behavioural loyalty measurements, attitudinal measurements and composite measurements.

In the early days, the majority of literature focused on the behavioural aspect of loyalty and ignored other customer factors. The behavioural approach involves the individual altering their behaviour, showing strong intentions to repurchase from one service provider over alternative service providers. Both the marketing and psychological literature indicates that re-purchasing intentions measure behavioural loyalty, switching intentions and exclusively purchasing intentions (Jones \& Taylor, 2007).

The second loyalty measure is attitudinal. The attitudinal approach considers both the emotional and psychological aspects inherent in loyalty. The attitudinal perspective reflects a sense of loyalty, engagement and allegiance. For instance, an individual may have a favourable attitude towards a bank, and may even recommend it to others, but they will not patronise that bank because it is too expensive for them to open an account with the bank. It takes more than a basic marketing transaction inducement to build attitudinal loyalty towards a product/service or business. Positive attitudes towards the product/service or business must be developed over a more extended period (Kumar \& Shah, 2004).

Indeed, commitment has a significant role to play in attitudinal loyalty; "since commitment reflects the customers' self-evaluation of the consumption context and the active decision to engage in a long-term relationship" (Evanschitzky, Gopalkrishnan, Plassmann\& Khanna, 2007). Moreover, affective commitment results in the customer being loyal because he or she wants to be loyal. Also, past research indicates that the strength of consumers' attitudes toward a product or service is an excellent indicator of their behavioural loyalty (Evanschitzky, Gopalkrishnan, Plassmann\& Khanna, 2007).

Attitudinal loyalty falls under an alternative measure of loyalty referred to as cognitive loyalty. The cognitive approach entails an individual completely reforming what he or she believes about the relationship with his or her service provider, based on a consciousus evaluation of attributes or the conscious evaluation of the rewards and benefits associated with re-patronage (Lee \& Cunningham, 2001).

The composite measurement of loyalty is a combination of the first two dimensions, behavioural and 
attitudinal intentions. Loyalty is measured utilizing customers' product preferences, the propensity of brand switching, the frequency of purchase and the total amount of purchase (Pritchard \& Howard, 1999). Pritchard and Howard (1999) argue that operationalising both attitude and behaviour in the measurement of loyalty significantly enhances the probability of building loyalty. Thus, the composite measurement approach has been utilised and supported as a beneficial tool to understand customer loyalty in a whole variety of areas of study from retailing to recreation, hotels, and airlines (Pritchard \& Howard, 1999).

Customer loyalty is considered a vital key to organisational success and profitability (Divett, Crittenden \&Henderson, 2003). Those consumers that demonstrate the highest levels of loyalty toward the product or service activity tend to repurchase more often and spend more money. As a result, a great deal of research attention is focused on the identification of effective methods of actively enhancing loyalty, including loyalty programs such as point reward schemes (Lach, 2000).

Ramanathan and Ramanathan (2011) stated that the ability of an organisation to attract and retain customers is vital to its success. However, customers are often retained for long periods but without a genuine relationship ever being developed.

The importance of customer loyalty to businesses cannot be said to be underestimated or overemphasised enough and has been widely acknowledged by managers, corporate executives as well as scholars who have resulted in the myriad of definitions and interpretation of the concept. Thus, for businesses to maximize profit and ensure long-term success, it is vital to building up a beneficial relationship with clients through customer loyalty.

Customer loyalty is the strength of a customer's dispositional attachment to a brand and his or her intention to repurchase the brand in the future'". In the ever-evolving and competitive business environment, customer loyalty is an essential factor for the survival of a business. The concept of customer loyalty is divided into three parts namely: stochastic, deterministic and composite. The stochastic approach can be said to be behavioural whereas the deterministic approach is attitudinal. However, the composite approach is a combination of both attitudinal and behavioural approaches. Loyalty thus evolves from the process of purchase to satisfaction then thirdly to trust and commitment which progresses into customer loyalty (Rundel-Thiele, 2006).

\section{Loyalty model propounded by Osagie 2020}

Figure 4: Customer Loyalty Circle

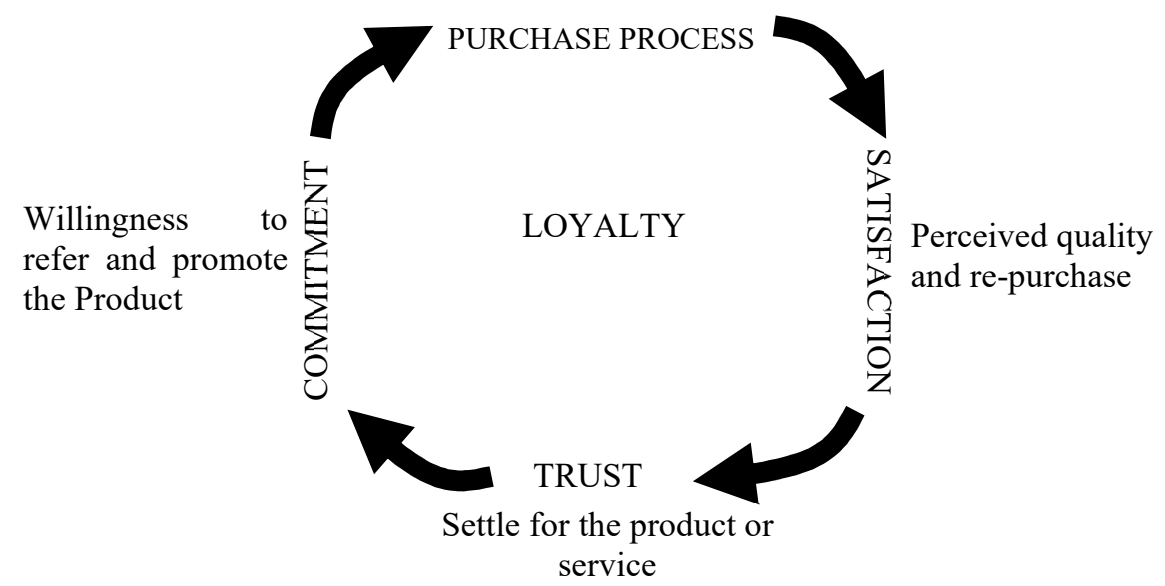

Purchase process: This is the first stage in the evolvement of customer loyalty. It has been observed that the purchasing environment has come to be a paramount concern in making purchasing decisions, instead of buying the product/service that has the lower price, the customer instead weighs a series of additional factors when considering what the true cost of the product/service is to him/her.

Customer satisfaction: This is an attribute that result in customer loyalty. It depends on customer perceived quality and value attached to a particular product or service.

Trust: Customer trust for a product/service depends on product attributes, customer relationship and trustworthiness. At this point loyalty is considered from the attitudinal point of approach because, for a product or service to gain customer trust emotional attachment to a brand must be involved.

Commitment: Customers commitment to a product/service enables him/her to play a significant role in the development of attitudinal loyalty. It reflects the customer's self-evaluation of consumption context and the active decision to engage in a long-term relationship. This entails the customer's willingness to repurchase, refer and promote the product/service or business, with high sense of price tolerance (willingness to pay more).

Bagram and Khan (2012) explain further that customer satisfaction and customer retention are two primary attributes that result in customer loyalty. Whereas customer satisfaction depends on the perceived quality and value, 
customer retention depends on product attributes, customer relationship and trustworthiness.

Although customer loyalty might be challenging to sustain, it is more economically prudent in retaining existing customers than it is to win new ones (Kumah\& Shah, 2004). Gronholdt, Martensen and Kristensen (2000) pointed out that the customer loyalty is composed of four indexes; including the customer repurchase intention, price tolerance, willingness of recommending company or products to others and customer's cross-buying intention. Yao Dan (2011) averts that no matter the evaluation from multidimensional, the connotation of customer loyalty should reflect not only the customer's behavioural characteristics (such as repeat purchase) but also the emotional characteristics of customer loyalty (such as customer's love for the products or service, the attachment should be positive, active and sustainable).

\section{Problem Tolerance}

Customers can tolerate some minute delay in e-service transactions delivery, but may not accept transaction diversion. Therefore, there are likely some factors between the loyalty of customers and their zone of tolerance to service failure.

Problem tolerance is an innovative concept that has attracted considerable attention in the service marketing arena (Lobo, 2009). It is the extent to which customers recognise and are willing to accept variation in service performance. The zone of tolerance (ZOT) is "the difference between the desired service and the level of service considered adequate" (Zeithaml, Berry\& Parasuraman, 1993). According to Zeithaml, Bitner and Gremler (2009), one can consider the "zone of tolerance" as a range in which customers do not particularly notice service performance. The zone of tolerance recognises that a consumer enter service encounters with different expectation levels, desired service' at the top and 'adequate service' at the bottom of the scale (Parasuraman, 2004). The desired service is "the level of service the customer hopes to receive and the adequate service is "the level the customer will accept". The customer satisfaction will result as long as customer perception of service performance, fall in this zone of tolerance (Zeithaml et al., 1993).

Figure 5: Zone of Tolerance

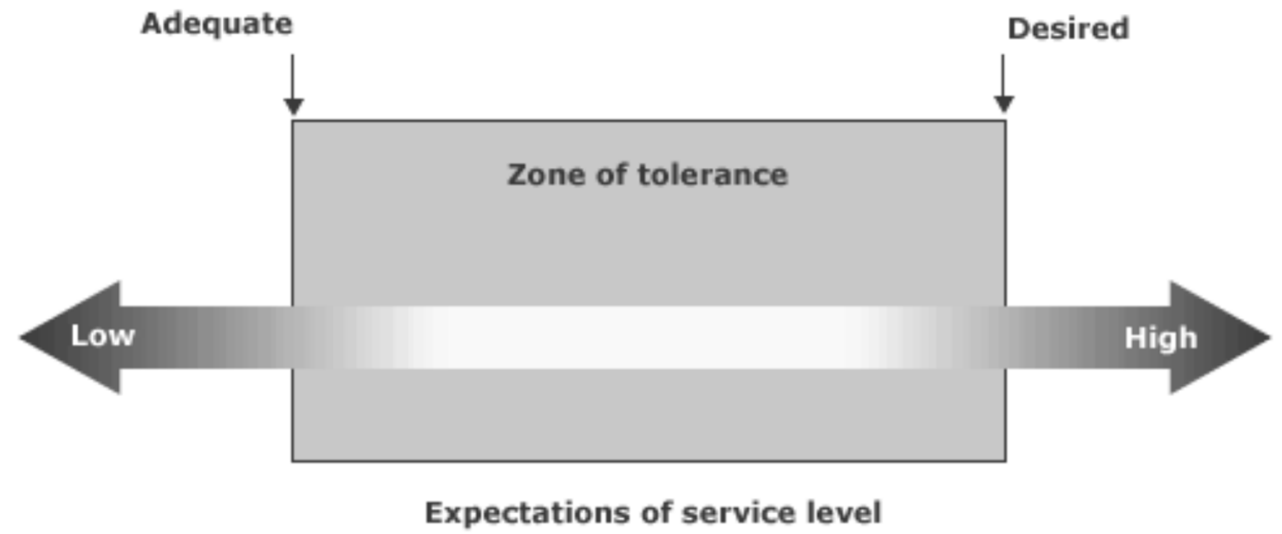

Source:Parasuraman, Berry and Zeithaml (1991)

There appear to be three main, though overlapping, applications of the zone; as a description of an outcome state, a description of a range of pre-performance expectations, and as the satisfactory range of in-process service performances. Poiesz and Bloomer (1991) proposed that the zone of tolerance becomes a unifying construct between expectations, performance and outcomes. Zone of tolerance raises the question of the basis of expectation formation (Zsófia, Kenesei, Keszey \& Tamara, 2014).

Consumers tend to act with negative emotion as service failure occurs, which could lead to consumers switching service providers (Roos, 1999). Due to inconsistencies in service delivery, Grönroos (2001) proposes that every customer has a zone of tolerance, and the perceived zone of tolerance varies for every customer. Johnston (1995) categorises expected service and actual service in the service process into three types: fully acceptable, acceptable and unacceptable, with the first two known as the tolerance zone.

According to Gwynne, Devlin and Ennew (2000), United Bank for Africa Plc., First Bank of Nigeria Plc., Zenith Bank Plc., and AccessBank are service provider's that operate in a highly competitive market of Nigeria. Their long-term success is determined by their ability to maintain and expand a large and loyal customer base. Maintaining loyal customer base may be achieved only when they meet up to their customers' expectations of service delivery. When deciding the level of service delivery, these banks probably need to keep their customers' zone of tolerance in mind. The zone of tolerance represents the range of service performance that customers can tolerate. It is essential because it is central to customer's evaluation of service quality and satisfaction, and it helps managers to analyse the effectiveness of service quality and to identify problem areas that need improvement (Lo 
YL, Cavana \& Corbett, 2002). The concept of a zone of tolerance is highly useful when trying to understand variability in customers' service expectations and perceptions as well as customers' satisfaction.

\section{Methodology}

This section discusses the method, techniques, various steps and procedures the researcher employed in administering, collecting and analysing the data for this research work. The idea behind this section is to explain, as well as give reasons on the procedures used in collecting and analysing data in this study.

\section{Research Design}

Research design is defined as a logical model that guides the researcher in the various stages. It is a planned strategy and structure in the investigation, conceived to acquire answers to questions as validly, objectively, accurately and economically as possible (Fisher, 2007).

Adopted by the researchers is the Quasi-experimental research design because the elements under study (human beings) are flexible, and are not controlled by the researchers. The cross-sectional survey was also adopted because it relies on a sample of elements from the population of interest measured at a single point.

\section{Population of the Study}

Population is a census of all items or subject that possess the characteristics or knowledge of the studied phenomenon (Barney, 2000). Therefore, the population was drawn from the e-banking customers of quoted deposit money banks with international authorisation, in Nigeria because of their involvement in international banking as well as e-service banking. The population of the customers is estimated to be over 4million (Four million) $(\mathrm{CBN}$ June 2018).

Table 1: List of Quoted Deposit Money Banks with International Authorization in Nigeria

\begin{tabular}{|l|l|}
\hline S/NO & Names of Banks \\
\hline 1 & Access Bank Plc \\
\hline 2 & Diamond Bank Plc \\
\hline 3 & Fidelity Bank Plc \\
\hline 4 & First City Monument Bank Plc \\
\hline 5 & First Bank of Nigeria Limited \\
\hline 7 & Guaranty Trust Bank Plc \\
\hline 8 & Skye Bank Plc/Polaris Bank \\
\hline 9 & Union Bank of Nigeria Plc \\
\hline 10 & United Bank for Africa Plc \\
\hline
\end{tabular}

Source: Central Bank of Nigeria (6 June 2018).

\section{Sample Size and Sampling Technique}

Total number of electronic banking customers in Nigeria is above 4 million (CBN, 2018). We applied Krejcie and Morgan (1970) formula to determine the sample size for this population which came out to be 384.

$\mathrm{s}=\mathrm{X}^{2} \mathrm{NP}(1-\mathrm{P}) \div \mathrm{d}^{2}(\mathrm{~N}-1)+\mathrm{X}^{2} \mathrm{P}(1-\mathrm{P})$

where $\left.X^{2}=(1.96) 2=3.841, p=0.50, d=0.05\right)$

$\mathrm{s}=(3.841)(4,000,000)(0.50)(1-0.50) \div(0.05)^{2}(4,000,000-1)+3.841(0.5)(1-0.5)$

$\mathrm{s}=3,841,000 \div(0.05)^{2}(4,000,000-1)+0.96025$

$\mathrm{s}=3,841,000 \div 10,000.95775$

$\mathrm{s}=384.1$

Sampling techniques are broadly grouped into probability or non-probability sampling technique. The probability sampling techniques give every element in the population a known and equal chance of being selected from the sample while the non-probability sampling techniques give room for bias and the application of experience and knowledge which are intuitively driven and can lead to error. Therefore, having arrived at a convenient sample size of 384 , the researcher increased the sample size to 430 , to allow for wider coverage. A probability simple random sampling was utilized in picking the 430 respondents.

\section{Data Analysis Techniques}

This study employed the use of frequency and percentages, pie and bar chart in answering research questions and demographic data of the respondents, Kendall's Tau-b correlation coefficient was used in testing the hypotheses one and two, while partial correlation was adopted in testing hypothesis three formulated for the study, at 0.05 level of significance. This technique (Kendall- Tau-b) is utilised because it is more effective in determining whether two non-parametric data samples with ties are correlated as well as analysing ordinal data, such as this. 
The SPSS (version 22) was employed in computing the data.

\section{Result/Findings}

\section{Demographic Characteristics}

A total of Four hundred and thirty (430) copies of questionnaire were distributed to the customers of deposit money bank with international authorization in South-South, Nigeria. Out of Four hundred and thirty (430) copies of questionnaire distributed in this study, four hundred and eleven (411) were returned. This represent $95.58 \%$ rate of return. The researcher discovered that the entire questionnaire returned where correctly filled.

\section{Demographic Data}

Fig 6 Questionnaire Distribution of Respondents

\section{Bar chart on questionnaire distribution based on banks}

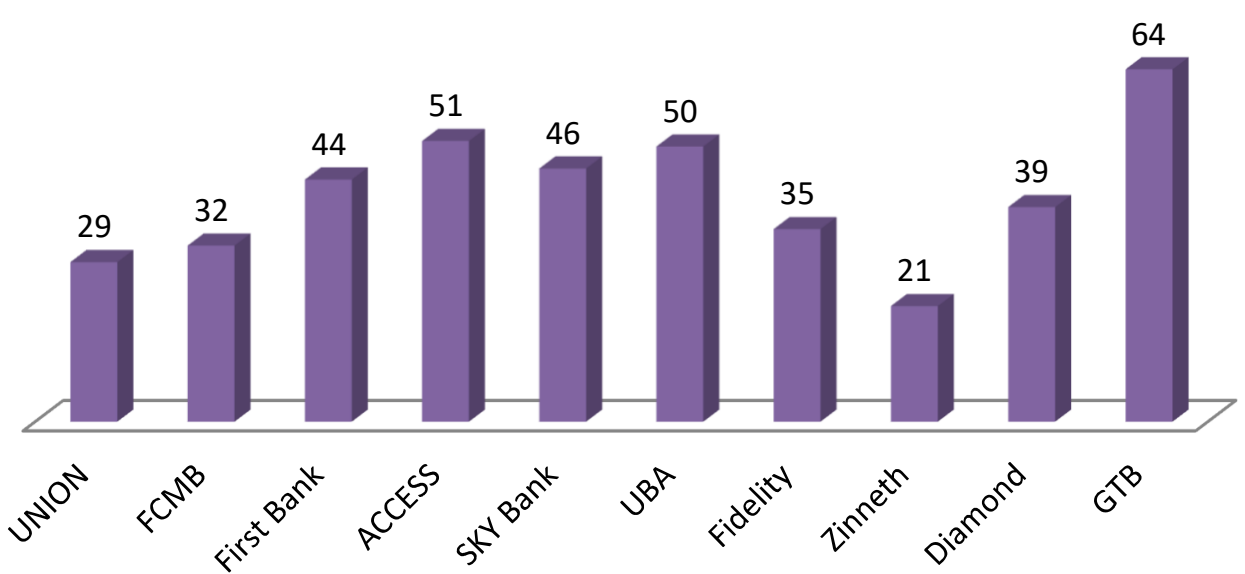

Fig 7 Percentage distribution of respondents on Gender

\section{Pie chart distribution of respondents on gender}
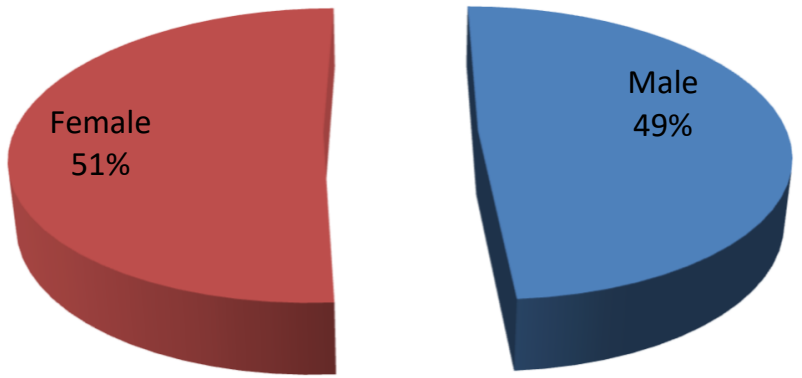

From the above table, 201(49\%) of the respondents were male, while $210(51 \%)$ of the respondents were females. 
Fig 8 Percentage distribution of respondents on Age

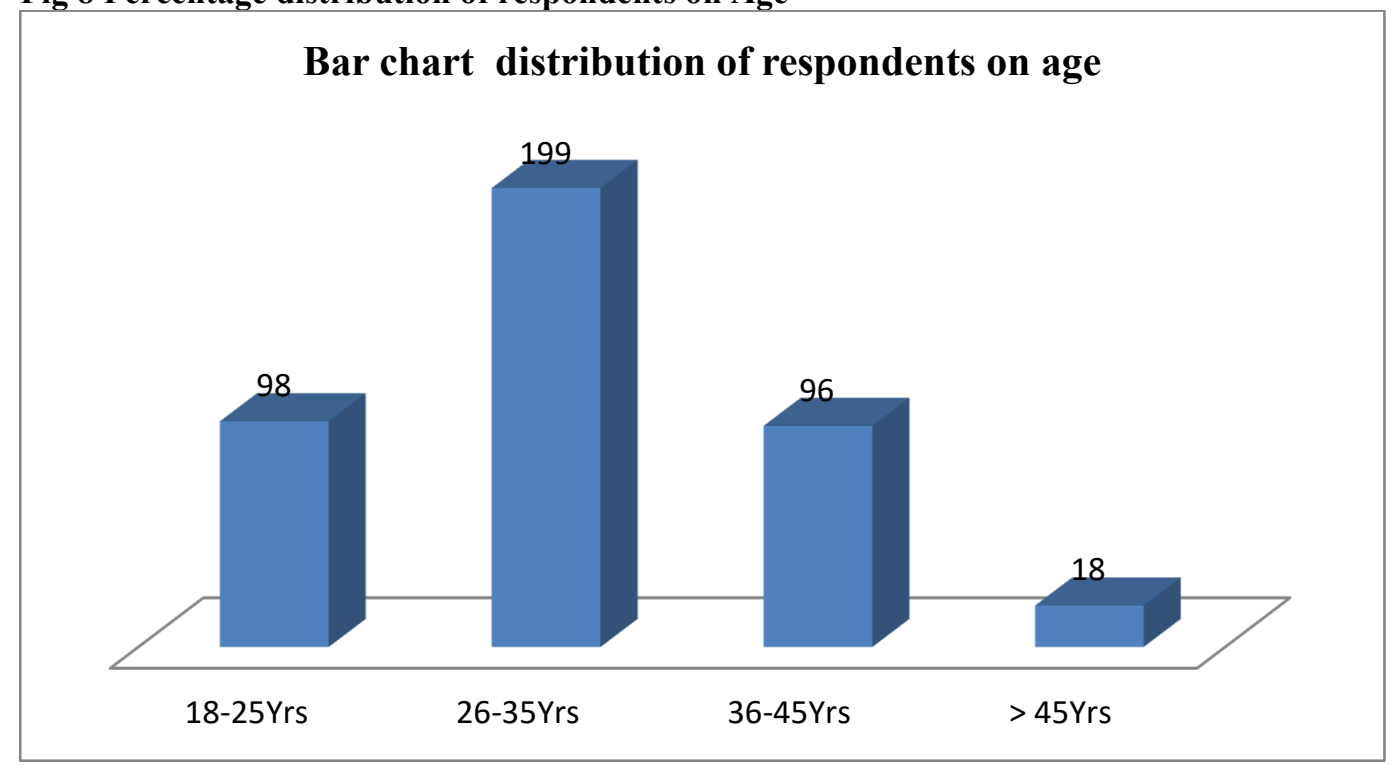

From the above bar chart, $98(23.84 \%)$ of the respondents were between $18-25$ years of age, $199(48.42 \%)$ of them were between 26-35years, $96(23.36 \%)$ of them were between $36-45$ years, while $18(4.38 \%)$ of them were above 45 years.

Fig 9 Percentage distribution of respondents on educational qualification

\section{Bar chart distribution of respondents on educational qualification}

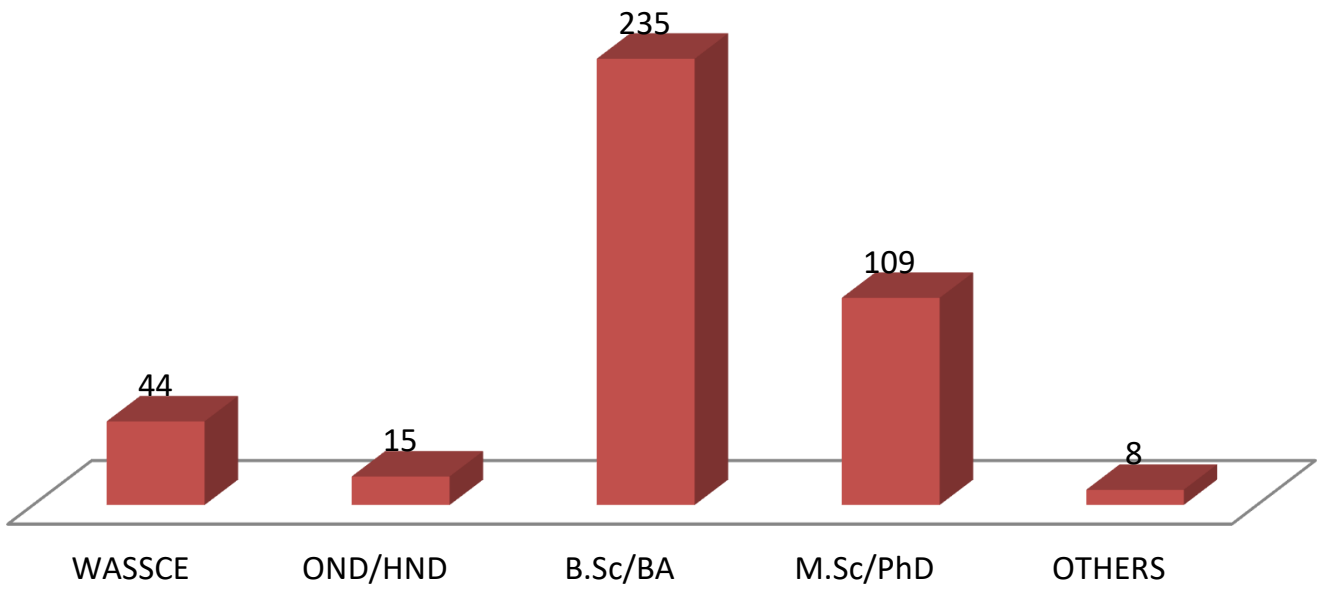

From the above bar chart, 44(10.71\%) of the respondents had WASSCE as their highest educational qualification, $15(3.65 \%)$ of them had OND/HND, 235(57.18\%) of them had B.Sc./BA, 109(26.52\%) of them had M.Sc./PhD, while $8(1.95 \%)$ of the respondents had other educational qualification.

Table 2: Mean and Standard Deviation of Responses on Interactivity

\begin{tabular}{|c|c|c|c|}
\hline Items & Mean & $\begin{array}{c}\text { Std. } \\
\text { Deviation }\end{array}$ & Variance \\
\hline $\begin{array}{l}\text { The bank's website has interactive features makes it easy for her online } \\
\text { customers' }\end{array}$ & 3.707 & 1.0096 & 1.019 \\
\hline Customers can freely interact with the bank' & 3.621 & 1.0872 & 1.182 \\
\hline It is easy for customers to freely exchange ideas and complains & 3.513 & 1.2108 & 1.466 \\
\hline $\begin{array}{l}\text { Mybank's website has interactive features which makes it easy for me to } \\
\text { complete my online tasks }\end{array}$ & 3.612 & 1.0861 & 1.180 \\
\hline Interactivity (INTTM) & 3.5831 & .93921 & .882 \\
\hline
\end{tabular}

\section{Source: Computer Result 2019}

Interactivity construct was measured using four questionnaire items which were developed on a five-point 
Likert scale. The item labels are shown above. The mean of the three items was calculated to obtain the overall mean response on the interactivity construct (INTTM). The overall mean response on the items (3.58) shows that the interactivity on the bank electronic platform is judged fairly good. The customers see the platforms as serving the purpose of enabling them to carry out their e-transactions and freely exchange ideas and complain (3.51).

Table 3: Mean and Standard Deviation of Responses on Customer Support Items

\begin{tabular}{|c|c|c|c|}
\hline Items & Mean & $\begin{array}{r}\text { Std. } \\
\text { Deviation }\end{array}$ & Variance \\
\hline Bank website usually gives personal attention to customers & 3.515 & 1.0377 & 1.077 \\
\hline $\begin{array}{l}\text { Bank e-service web enables the firm customers to perform online } \\
\text { transactions to meet their needs }\end{array}$ & 3.946 & .9750 & .951 \\
\hline Bank e-service website is suitable for the specific needs of their customers & 3.840 & .9921 & .984 \\
\hline $\begin{array}{l}\text { Bank administrators of our online banking platform tell you exactly when } \\
\text { the services will be performed }\end{array}$ & 3.388 & 1.2105 & 1.465 \\
\hline Customer Support (CSTM) & 3.6753 & .84366 & .712 \\
\hline
\end{tabular}

Source: Computer Result 2019

Customer support was measured using four questionnaire items which were developed on a five-point Likert scale. The item labels are shown above. The mean of the four items was calculated to obtain the overall mean response on the customer support construct (CSTM). The overall mean response on the items (3.67) shows that the support the customers receive from the banks in the use of their electronic platform is fairly good.

Table 4: Mean and Standard Deviation of Responses on Problem Tolerance

\begin{tabular}{|l|r|r|r|}
\hline Items & Mean & Std. Deviation & Variance \\
\hline A customer's loyalty to his bank enable him tolerate service & 3.411 & 1.1016 & 1.213 \\
\hline Loyal customers still repurchase and share products & 3.356 & 1.0419 & 1.086 \\
\hline Competition affect customers level of tolerance for service failure & 3.215 & 1.0534 & 1.110 \\
\hline Service failure tolerance reduces when dissatisfaction increases & 3.461 & 1.0920 & 1.193 \\
\hline Problem Tolerance (PLTM) & 3.3579 & .82227 & .676 \\
\hline
\end{tabular}

Source: Computer Result 2019

Problem tolerance construct was measured using four questionnaire items which were developed on a fivepoint Likert scale. The item labels are shown above. The mean of the four items was calculated to obtain the overall mean response on the problem tolerance construct (PLTM). The overall mean response on the items (3.36) shows that the customer's problem tolerance on their banks electronic platform is judged fairly good. Therefore, competition does not contribute to customer's level of tolerance for service failure (3.22).

Table 5: Mean and Standard Deviation of Responses on Moderating Effect of Customer Technology Adoption

\begin{tabular}{|l|r|r|r|}
\hline Responses & Mean & $\begin{array}{c}\text { Std. } \\
\text { Deviation }\end{array}$ & Variance \\
\hline $\begin{array}{l}\text { Technology makes it possible for customers to easily access their banks } \\
\text { online platform and perform online transactions. }\end{array}$ & 4.264 & .9568 & .915 \\
\hline $\begin{array}{l}\text { It is usually less difficult for customers to figure out how to effectively } \\
\text { adopt new technologies and use them in their e-service dealings }\end{array}$ & 3.824 & 1.1009 & 1.212 \\
\hline $\begin{array}{l}\text { Customers can figure out new high-tech products and services of their bank } \\
\text { without help from an information technology expert }\end{array}$ & 3.838 & 1.1121 & 1.237 \\
\hline $\begin{array}{l}\text { Customers knowledge of ICT encourage their adoption of technology- } \\
\text { based activities of their bank's e-service channels }\end{array}$ & 4.066 & 1.0576 & 1.118 \\
\hline Customer Technology Adoption (CTTM) & 3.9988 & .86087 & .741 \\
\hline
\end{tabular}

\section{Source: Computer Result 2019}

Customer technology adoption construct was measured using four questionnaire items which were developed on a five-point Likert scale. The item labels are shown above. The mean of the four items was calculated to obtain the overall mean response on the customer technology adoption construct (CTTM). The overall mean response on the items (4.00) shows that the customer technology adoption on their banks electronic platform is judged good. Therefore, it is usually difficult for customers to figure out how to effectively adopt new technologies and use them in their e-service dealings (3.82). 


\section{Amos Model}

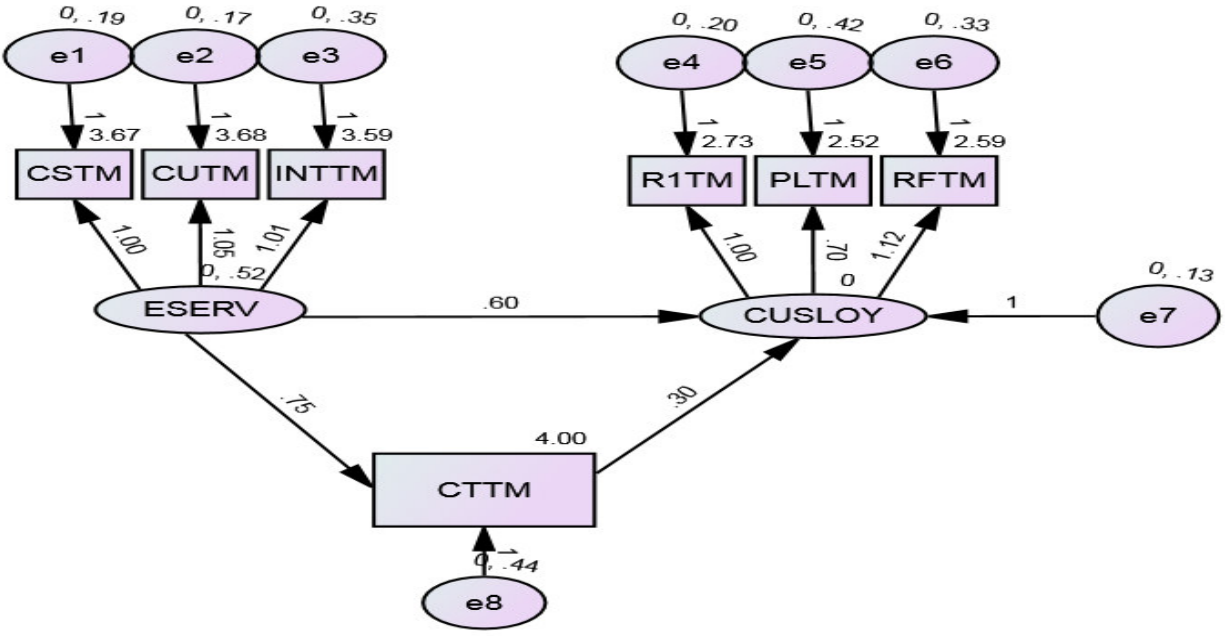

Table 6: Baseline Comparisons

\begin{tabular}{|l|c|c|c|c|r|}
\hline Model & $\begin{array}{c}\text { NFI } \\
\text { Delta1 }\end{array}$ & $\begin{array}{c}\text { RFI } \\
\text { rho1 }\end{array}$ & $\begin{array}{c}\text { IFI } \\
\text { Delta2 }\end{array}$ & $\begin{array}{c}\text { TLI } \\
\text { rho2 }\end{array}$ & CFI \\
\hline Default model & .976 & .937 & .982 & .952 & .982 \\
\hline
\end{tabular}

Five "goodness" of fit indices were calculated to examine the structural model. The corresponding values revealed evidence of a good fit based on the recommendation of Kline (1998), Schumacker \& Lomax, 2004, Hu and Bentler, 1998, X2/df $=4.01(<=5)$, Tucker-Lewis index $(\mathrm{TLI})=0.95(>=0.9)$, Root mean square error of approximation $(\mathrm{RMSEA})=0.023(<=0.08)$, Comparative Fit Index $(\mathrm{CFI})=0.98(>=0.90$ or $>=0.96)$, Normed Fit Index $=0.98$.

Table 7: Overall Model (CMIN)

\begin{tabular}{|l|r|r|r|r|r|}
\hline Model & \multicolumn{1}{|c|}{ NPAR } & \multicolumn{1}{c|}{ CMIN } & \multicolumn{1}{c|}{ DF } & \multicolumn{1}{c|}{ P } & \multicolumn{1}{c|}{ CMIN/DF } \\
\hline Default model & 19 & 29.138 & 8 & .000 & 3.642 \\
\hline Saturated model & 27 & .000 & 0 & & \\
\hline Independence model & 6 & 1187.118 & 21 & .000 & 56.529 \\
\hline
\end{tabular}

Table 7 above, show that the saturated model contains as many parameter estimates as there are available degrees of freedom or inputs into the analysis. The Saturated model is thus the least restricted model possible that can be fit by AMOS. By contrast, the Independence model is one of the most restrictive models that can be fit: it contains estimates of the variances of the observed variables only. In other words, the Independence model assumes all relationships between the observed variables are zero. Since the probability value of the chi-square test is smaller than the .05 level used by convention, it implies that the model fits the data.

\section{Testing of Hypotheses}

The hypotheses stated in this study were tested statistically in this section using Kendall tau-b. The result of the statistical testing was used to either accept or reject the null hypothesis formulated at 0.05 level of significance.

Table 8: Kendall Correlation between interactivity and problem tolerance in deposit money banks in Nigeria

\section{Correlations}

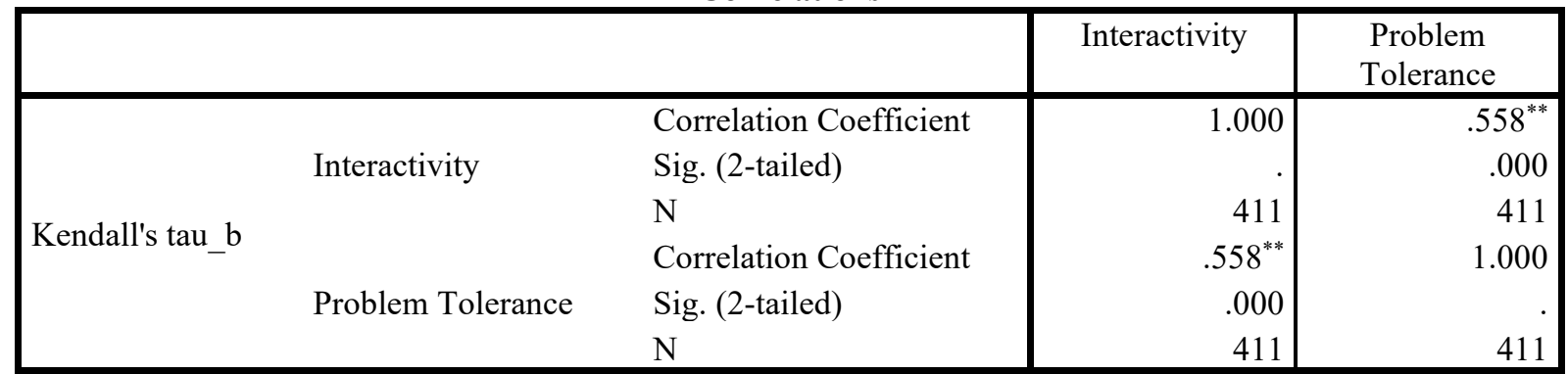

**. Correlation is significant at the 0.01 level (2-tailed).

From table 8 , the correlation coefficient $(\mathrm{r}=0.558)$ between interactivity and problem tolerance of deposit money banks is strong and positive. The coefficient of determination $\left(\mathrm{r}^{2}=0.31\right)$ indicates that $31 \%$ change in problem tolerance of deposit money banks can be explained by interactivity. The significant value of $0.000(\mathrm{p}<$ 
0.01) reveals a significant relationship. Based on that, the null hypothesis was rejected. Therefore, there is a significant relationship between interactivity and problem tolerance of deposit money banks in Nigeria.

Table 9: Kendall Correlation between customer support and problem tolerance in deposit money banks in Nigeria

\section{Correlations}

\begin{tabular}{|rll|r|r|}
\hline & & Customer Support & Problem Tolerance \\
\hline & & Correlation Coefficient & 1.000 & $.657^{* *}$ \\
Kendall's tau_b & Customer Support & Sig. (2-tailed) &. & .000 \\
& & $\mathrm{~N}$ & 411 & 411 \\
& & Correlation Coefficient & $.657^{* *}$ & .000 \\
& \multirow{2}{*}{ Problem Tolerance } & Sig. (2-tailed) & 4.000 \\
& & $\mathrm{~N}$ &. & 411 \\
\hline
\end{tabular}

**. Correlation is significant at the 0.01 level (2-tailed).

From table 9, the correlation coefficient $(r=0.657)$ between customer support and problem tolerance of deposit money banks is strong and positive. The coefficient of determination $\left(r^{2}=0.43\right)$ indicates that $43 \%$ change in problem tolerance of deposit money banks can be explained by customer support. The significant value of 0.000 $(\mathrm{p}<0.01)$ reveals a significant relationship. Based on that, the null hypothesis was rejected. Therefore, there is a significant relationship between customer support and problem tolerance of deposit money banks in Nigeria.

Table 10: Partial Correction on the influence of customer technology adoption on the relationship between e-service quality and customer loyalty

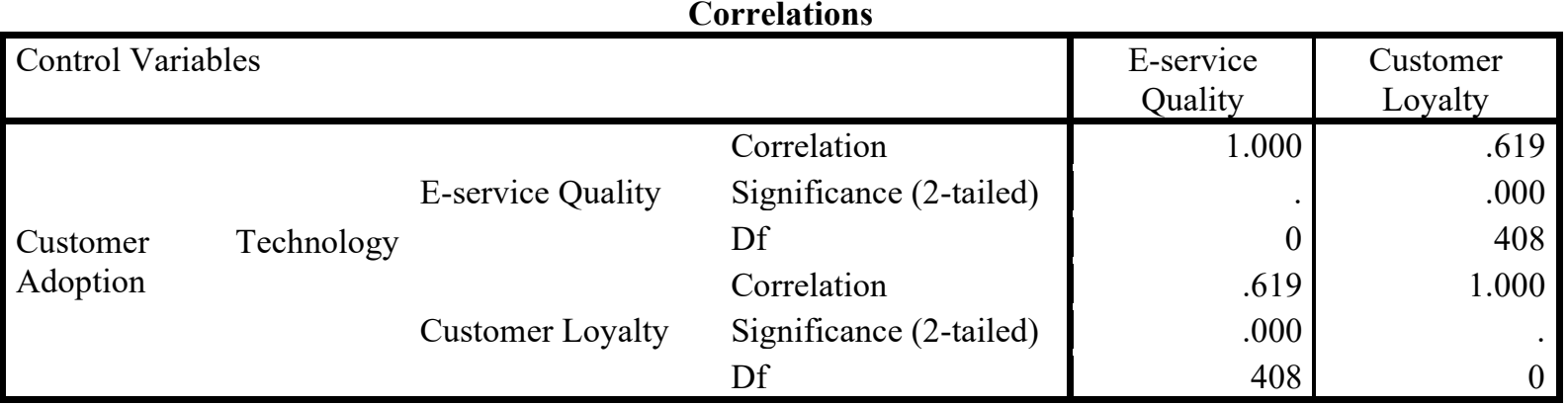

From table 10, above, the correlation coefficient $(\mathrm{r}=0.619)$ on the influence of customer technology adoption on the relationship between e-service quality and customer loyalty of deposit money banks is strong and positive. The coefficient of determination $\left(\mathrm{r}^{2}=0.38\right)$ indicates that $38 \%$ of customer technology adoption influences the relationship between e-service quality and customer loyalty of deposit money banks. The significant value of 0.000 $(\mathrm{p}<0.01)$ reveals a significant relationship. Based on that, the null hypothesis is rejected. Therefore, there is a significant influence of customer technology adoption on the relationship between e-service quality and customer loyalty of deposit money banks in Nigeria.

\section{Discussion of Findings and Implications \\ Interactivity and Customer Loyalty}

The findings revealed a significant relationship between interactivity and customer loyalty. This was validated by the fact that the customers' bank's website allows them to interact with its facilities to receive tailored information, bank's website has interactive features which makes it easy for customers' to complete their online tasks, they can freely interact with their bank's website to get information tailored to their specific needs and it is easy for them to exchange ideas freely and complains with their bank through effective e-service interaction. Das (2009) in his argument posits that regarding interactivity, the consumer relationship management plan may not be most useful or gainful in the service sector. Also, Yu \& Wei (2012) demonstrated that peer communication and socialisation by means of social media influences not only the community members' product attitudes directly, but also their purchase intentions indirectly. This implies that customer satisfaction as well as interactivity is one of the main antecedents for e-loyalty, and increase in satisfaction will enhance the commitment and trust of customers. The level of interaction an organization have with customers, will determine consumers' commitment and loyalty. Therefore, this agrees with the findings of the present study.

\section{Customer Support and Customer Loyalty}

The findings revealed a significant relationship between customer support and customer loyalty. This was validated by the fact that customers' banks website usually gives personal attention to them, their bank's e-service web enables them to perform online transactions to meet their needs, their bank's e-service website is suitable for 
their specific needs and their bank administrators of online banking platform tells them exactly when the services will be performed. Bowen and Chen (2001) opined that extreme customer support and consequent satisfaction leads to customer loyalty. Thus, delighted customers are less prone to offers from competition (Fornell, 1992). Similarly, Anton (1996) asserted that "customer support is usually prone to satisfaction and satisfaction is positively associated with repurchase intentions and the likelihood to recommend a product or service offering. These assertions all agree with the findings of the present study.

This implies that when customers are not satisfied with the service or product support offering they leave the company. Through positive customer support, customer needs and wants are fulfilled, thereby bringing about satisfaction and retention. Also, by firm's continuous support to customers, they retain their old customers, which is instrumental to getting new customers.

\section{Influence of Customer Technology Adoption on the relationship between E-service Quality and Customer Loyalty}

The findings revealed a significant influence of customer technology adoption on the relationship between eservice quality and customer loyalty. This was validated by the fact that technology makes it possible for customers to access their bank's online platform and perform online transactions easily, it is usually less difficult for them to figure out how to effectively adopt new technologies and use them in their e-service dealings, they can figure out new high-tech products and services of their bank without help from an information technology expert. Samer (2018) studied the effect of banks website service quality and e-satisfaction on e-loyalty in Swedish banks. The findings showed that website service quality and e-satisfaction have a strong positive correlation with e-loyalty. This supports the findings of the present study.

Users who are experienced in using computers and the Internet are influence to use Internet banking services (Lassar, Manolis \& Lassar 2005). Shih and Fang (2003) agreed that the factors of behaviour intention to use the internet banking, which is the actual usage of banking transaction are attitude, subjective norms, perceived and relative advantages of the Internet banking, and normative influences. Laforet and Li (2005) stated that the customer adoptions of Internet banking are predetermined by many factors like demographics, motivation and behaviour towards technology which affect customers' willingness to accept it. It is also found that prior experience with computers and technology can influence customer's attitudes towards technology. These deductions validate the findings of the present study.

The implication is that individuals who are skilled and always using the internet significantly affects the acceptance of internet banking services, which brings about more patronage and loyalty among customers. Moreover, compatibility and complexity of the internet banking will determine the acceptance of the internet banking usage. Furthermore, the level of awareness towards importance and benefits of internet will encourage ebanking among customers, retention and loyalty.

\section{Summary of Findings, Conclusion and Recommendation}

Drawing from the discussion of findings above, the following summary was deduced;

(a) There is a significant relationship between interactivity and customer loyalty. This implies that customer satisfaction as well as interactivity is one of the main antecedents for e-loyalty, and increase in satisfaction will enhance the trust and commitment of customers.

(b) There is a significant relationship between customer support and customer loyalty. This implies that when customers are not satisfied with the service or product support offering they leave the company. Through positive customer support, customer needs and wants are fulfilled, thereby bringing about satisfaction and retention.

(c) There is a significant influence of customer technology adoption on the relationship between e-service quality and customer loyalty. This implies that individual who are skilled and always using the internet significantly affects the acceptance of internet banking services, which brings about more patronage and loyalty among customers.

\section{Conclusion}

From the findings of the study, the conclusion is reached. In this case, the study has filled the gap in literature by providing the knowledge base that when the quality of e-service is improved in deposit money banks; it increases customer loyalty. Also, the research has proven that interactivity, customization and customer support can increase customer loyalty among bank customers. Furthermore, the level of awareness towards the importance and benefits of internet will encourage e-banking among customers, retention and loyalty.

\section{Recommendations}

Based on the conclusion of this study, the following are recommended;

1. Deposit money banks should develop their websites, by making it more interactive and simply, as this 
2. Online banking should be made easier for customers to make use of. The websites should be developed to suit individual needs

3. More awareness and sensitization programmes should be given to customers on the need for e-banking. The benefits should be emphasized continuously.

4. Banks should make their websites more secured to encourage larger patronage and customer loyalty

\section{Contribution to Knowledge}

The study has bridged the gap in e-service quality and customer loyalty literature by providing an integrated view of the interactive relationship between interactivity and customer support on problem tolerance of a deposit money banks in Nigeria. Competitive spirit have been stirred among deposit money bank, towards improving their service quality for more customer retention and loyalty. The findings of the study have made a meaningful impact on people in business, having seen the key factors responsible for service quality. The outcome has brought to the knowing and understanding of bank managers and customers on the importance of technology adoption as a veritable tool in interactivity and customer support and its effect on problem tolerance. The study expanded the frontiers of knowledge in dynamic capabilities. It has formed a good reference material for researchers and academics in the field of marketing, banking, finance, economics etc.

\section{References}

Adeoye, B. W. (2007). Financial sector development and economic growth: The Nigerian Experience. Proceedings of Nigerian Economic Society (NES) Conference, 2007

Anaro, B. (2009). Banking sector in the Gambia lies in Nigeria's strength. Retrieved from http://www.businessdayonline.com/index.

Anton, J. (1996). Customer relationship management: Making hard decisions with soft numbers, Upper Saddle River, Prentice-Hall.

Auger, P. (2005). The impact of interactivity and design sophistication on the performance of commercial Websites for small businesses. Journal of Small Business Management,43(2), 119-137.

Bagram, M. M. M., \& Khan, S. (2012). Attaining customer loyalty!The role of consumer attitude and consumer behaviour. International Review of Management and Business Research, 1(1), 1-8. Retrieved from http://search.proquest.com/docview/1412868177?accountid=27304

Belanche,D.,Casaló,L.V., \& Flavián, C. (2011).Adopción de serviciospúblicos online: Unanálisis a través de la integración. RevistaEuropea de Dirección y Economía de la Empresa, 20, 41-56

Berkley, B.J., \& Gupta, A. (1994). Improving service quality with information technology.International Journal of Information Management, 14(2), 109-121.

Bowen, J.T., \& Chen, S.L. (2001). The relationship between customer loyalty and customer satisfaction. International Journal of Contemporary Hospitality Management, 13(5), 213-219.

Brady, M.K., Robertson, C.J., \& Cronin, J.J. (2002).Managing behavioural intentions in diverse cultural environments: An investigation of service quality, service value, and satisfaction for American and Ecuadorian fast-food customers. Journal of International Management, 7, 129-149.

Caruana, A. (2002). Service loyalty: The effects of service quality and the mediating role ofcustomer satisfaction. European Journal of Marketing, 36(7/8), 811-828.

Central Bank of Nigeria (6 June 2018). List of deposit money banks and financial holding companies operating in Nigeria, December 29, 2017

Central Bank of Nigeria (1995). Annual report and financial statements for the year ended 31st December 1994.

Chen, K., \&Yen, D. (2004). Improving the quality of online presence through interactivity.Journal of Information and Management, 42(1), 217-226

Chitty, B., Ward, S., \& Chua, C. (2007). An application of the ECSI model as a predictor of satisfaction and loyalty for backpacker hostels. Journal of Marketing Intelligence and Planning, 25(6), 563-580.

Choi, K.S., Cho, W.H., Lee, H., \&Kim, C. (2004). The relationships among quality, value, satisfaction and behavioural intention in health care provider choice: A South Korean study. Journal of Business Research, 57(80), 913-21.

Cyr, D., Hassanein, K., Head, M., \& Ivanov, A. (2009). The role of social presence in establishing loyalty in eservice environments. Interacting with Computers, 19(1), 43-56.

Daily Graphic News (August 2008) www.ghheadlines.com/.../ daily graphic.

Das, K. (2009). Relationship marketing research. An academic literature review and classification. Marketing Intelligence \& Planning, 27(3), 326-363.

Deloitte Employee Survey (2005). In Istvan, S. \& Zsolt, T. (2008). Customer loyalty problem in retail banking. International Conference on Management, Enterprise and Benchmark. May 30-31.Budapest, Hungary.

Divett, M., Crittenden, N.,\& Henderson, R. (2003). Actively influencing consumer loyalty.Journal of Consumer 
Marketing, 20(2), 109-126.

Ehigie, B. O. (2006). Correlates of customer loyalty to their banks: A case study in Nigeria.International Journal of Bank Marketing, 24 (7), 494-508.

Evanschitzky, H., Gopalkrishnan, R.I., Plassmann, H., Niessing, J. \& Meffert, H. (2007). The relative strength of affective commitment in securing loyalty in service relationships. Journal of Business Research, 59 (12), 1207-1213.

Fassnacht, M., \& Koese, I. (2006). Quality of electronic services: Conceptualizing and testing a hierarchical model. Journal of Service Research, 9, 19-37.

Fisher, M.L. (2007). Demand estimation and assortment optimization under substitution: Methodology and application, Operation Research, 55(6), 11-24.

Fornell, C. (1992). A national customer satisfaction barometer: The Swedish experience. Journal of Marketing, 56,6-21.

Furey, T.R. (1991). How information power can improve service quality.Planning Review, 19(3), 24-6.

Gao, Q., Rau, P.P., \&Salvendy, G. (2009). Perception of interactivity: Effects of four keyvariables in mobile advertising. International Journal of Human-Computer Interaction, 25(6), 479.

Goffin, K. (1994). Gaining a competitive advantagefrom support: Five case studies. European Services Industry, $1(4), 5-7$.

Goffin, K., \& New, C. (2001). Customer support and new product development.International Journal of Operations \& Production Management, 21(3), 275-301.

Gronholdt, L., Martensen, A.,\&Kristensen, K. (2000). The relationship between customer satisfaction and loyalty: Cross-industry differences.Total Quality Management, 11(4-6), 509-514. http://dx.doi.org/10.1080/09544120050007823.

Grönroos, C. (2001). Service management and marketing: A customer relationship approach, 2nd Edition, John Wiley and Sons, West Sussex.

Gwynne, A. L., Devlin, J. F., \&Ennew, C. T. (2000). The zone of tolerance: Insights and influences. Journal of Marketing Management, 16, 545-564.

Jamie Carlson \& Aron O'Cass, (2010). Exploring the relationships between e-service quality, satisfaction, attitudes and behaviours in content-driven e-service websites. Journal of Services Marketing, 24(2), 112-127.

Jiang, Z., Chan, J., Tan, B.C., \& Chua, W.S. (2010). Effects of interactivity on Website involvement and purchase intention. Journal of the Association for Information Systems, 11(1), 34-59.

Jones, T., \& Taylor, S.F. (2007). The conceptual domain of services loyalty: How many dimensions? Journal of Services Marketing, 21(1), 36-51.

Johnston, R. (1995). The zone of tolerance: Exploring the relationship between service transaction and satisfaction with overall service. International Journal of Service Industry Management,6(2),46-61.

Kumar, V., \& Shah, D. (2004). Building and sustaining profitable customer loyalty for the 21st century. Journal of Retailing, 80(4), 317-330.

Lach, J. (2000). Redeeming qualities.American Demographics, 22(5), 36-38.

Laforet, S., \& Li, X. (2005). Consumers' attitudes towards online and mobile banking in China. International Journal of Bank Marketing, 23(5), 362-380.

Lawless, M.W., \& Fisher, R.J. (1990).Sources of durable competitive advantage innew products. Journal of Product Innovation Management, 7(1), 35-44

Lassar, W.M., Manolis, C., \& Lassar, S.S. (2005). The relationship between consumer innovativeness, personnel characteristics and online banking adoption. International Journal of Bank Marketing, 23(2),176-199.

Lin, H. F.,\& Lee, G. G. (2005). Customer perceptions of e-service quality in online shopping.International Journal of Retail and Distribution Management,33(2), 161-176.

Lobo, A. C. (2009). Zone of tolerance as an effective management tool to assess service quality in Singapore's stockbroking industry. Journal of Service Marketing, 30, 39-53.

Loomba, A.P.S. (1998). Product distribution and service support strategy linkages: An empirical investigation. International Journal of Physical Distribution \& Logistics Management, 28(2),143-6.

Lowry, P.B., Spaulding, T., Wells, T., Moody, G., Moffit, K., \& Madariaga, S. (2006, January). A theoretical model and empirical results linking Website interactivity and usability

Lo, Y. L., Cavana, R. Y., \& Corbett, L. M. (2002). Quality and customer satisfaction in passenger railservices: Developing zones of tolerance for managing quality. IFSAM Conference, Gold Coast, Queensland, Australia.

Mathwick, C. (2002). Understanding the online consumer: A typology of online relational norms and behaviour.Journal of Interactive Marketing, 16(1), 40-55.

Osagie L.U., Justie O.N. \& Ezechirinum A. (2019). Information and Communication Technology Applications and Service Quality of Federal Universities in Nigeria. British Journal of Marketing studies, 7(5) 1-23.

Parasuraman, A. (2004). Assessing and improving service performance for maximum impact: Insights from a twodecade-long research journey. Performance Measurement and Metric, 5, 45-52. 
Poiesz, T. B. C., \& Bloomer, J. M. M. (1991). Customer (dis)satisfaction with the performance of products and services - The applicability of the (dis)confirmation paradigm. Marketing thought around the World: Proceedings from the European Marketing Academy Conference. Dublin, 2, 446-462.

Pritchard, M.P., Havitz, M.E., \& Howard, D.R. (1999). Analysing the commitment-loyalty links in service contexts. Journal of the Academy of Marketing Science, 27(3), 333-348.

Ramanathan, U., \& Ramanathan, R. (2011). Guests' perceptions on factors influencing customer loyalty - an analysis for UK hotels. International Journal of Contemporary Hospitality Management, 23(1), 7-25.

Reichheld, F.F. (2003). The one number you need to grow. Harvard Business Review, 81(12), 46-54.

Roos, I. (1999). Switching processes in customer relationship. Journal of Service Research, 2(1), 68-85.

Roos, I., \& Edvardsson, B. (2008). Customer-support service in the relationship perspective. Managing Service Quality, 18(1),87-107.

Rundle-Thiele, Sh. (2006). Exploring loyal qualities: Assessing survey-based loyalty measures. Journal of Services Marketing, 19(7), 492-500.

Saleem and Rashid (2011). Relationship between customer satisfaction and mobile banking adoption in Pakistan. International Journal of Trade, Economics and Finance,2(6), 1-8

Samer, A. (2018). The effect of banks website service quality and e-satisfaction on e-loyalty. International Journal of Business and Management. Vol. 13, No. 8.

Santos, Jessica. (2003). E-service quality: A model of virtual service quality dimensions. Marketing Service Quality, 13(3), 233-246.

Scott, J. L (2002). Assessment of customer satisfaction in the banking industry. International Journal of Marketing, $56(6), 135-157$

Shih, Y., \& Fang, K. (2003). The use of the decomposed theory of planned behaviour to study internet banking in Taiwan. Internet Research Electronic Network Application Policy. 14(3), 213-223.

Sohn, C., \& Tadisina, S. K. (2008). Development of e-service quality measure for the Internet-based financial institutions.Total Quality Management \& Business Excellence, 19(9), 903-918.

Vargo, S.L., \& Lusch, R.F. (2004b). The four service marketing myths-remnants of a goods-based, manufacturing model. Journal of Service Research, 6(4), 324-35.

Voorveld, H. A., Van Noort, G., \& Duijn, M. (2013). Building brands with interactivity: The role of prior brand usage in the relation between perceived website interactivity and brandresponses. Journal of Brand Management.

Wu, L.W. (2011). Inertia: Spurious loyalty or action loyalty? Asia Pacific Management Review, 16(1), 31-50.

Yao Dan (2011). Empirical research of perceived value as a mediator between group-buying service quality and customer loyalty incatering industry. Nanjing University.

Yousaf, A., \& Steene, A. (2011). The impact of ICT in the eyes of hotel managers (Cyprus), Master's Thesis, Department of Business Studies, Sodertorns University, Cyprus. sh.diva-Portal.org.

Yu, C., Wei, J., \& Wang, X. (2012). Social media peer communication and impacts on purchase intentions: a consumer socialisation framework. Journal of Interactive Marketing,26(4), 198-208.

Zeithaml, V.A., Bitner, M. J., \& Gremler, D.D. (2009). Services marketing: Integrating customer focus across the firm: (4th. ed). New York: McGraw Hill.

Zeithaml, V.A., Berry, L. L., \& Parasuraman, A. (1993). The nature and determinants of customer expectations of service. Journal of Academy of Marketing Science, 21, 1-12.

Zeithaml, V., Parasuraman, A., \& Malhotra A. (2002). Service quality delivery through websites: A critical review of extant knowledge. Journal of Academy of Marketing Science, 30, 362-375.

Zins, A.H. (2001). Relative attitudes and commitment in customer loyalty models, some experiences in the commercial airline industry. International Journal of Service, 12(3), 269-294.

Zsófia, K., \& Tamara, K. (2014). An enhanced SERVQUAL approach to measure service quality in higher education. Journal of European Marketing Academy, 1, 148-155. 